\title{
СЛАВНИЙ ЮВІЛЕЙ ПРОФЕСОРА АНТОНІНИ ОЛЕКСІЇВНИ РУДЕНКО
}

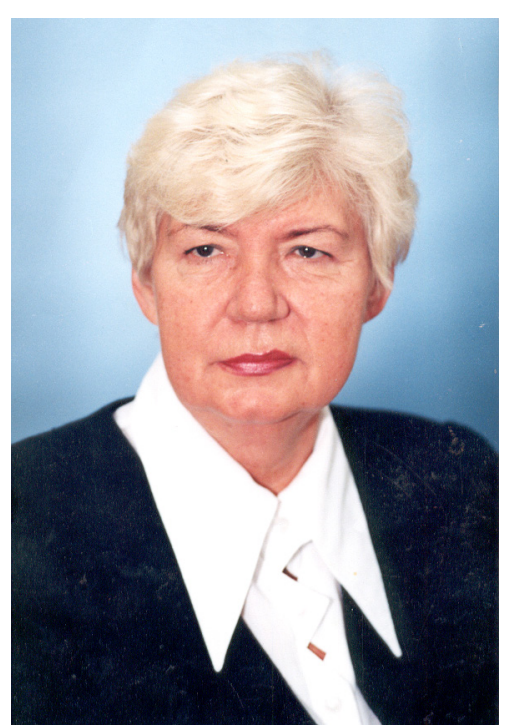

6 грудня 2016 р. Всеукраїнська асоціація інфекціоністів і колеги відзначили славний ювілей відомого українського вченого, Заслуженого лікаря України, кавалера відзнаки НАМН України «Знак пошани», доктора медичних наук, профресора Антоніни Олексіївни Руденко.

А.О. Руденко народилась у м. Дніпропетровську. В 1951 р., у 15 років, вступила в Київську школу (медичне училище) медичних сестер, після чого з 1954 по 1957 рр. працювала за призначенням медичною сестрою в І-ій лікарні м. Києва.

У 1957 р. Антоніна Олексіївна вступила в Київський медичний інститут ім. О.О. Богомольця на лікувальний факультет і в 1963 р. отримала диплом лікаря. Лікарську діяльність Антоніна Олексіївна розпочала в селі Веселинівка Переяслів-Хмельницького району Київської області, де очолила дільничну лікарню. Потім у 1964-1969 рр. працювала лікарем лікарні № 10 Московського району м. Києва.

Творча вдача та зацікавленість інфекційними хворобами привела Антоніну Олексіївну до Київського НДІ інфекційних хвороб МОЗ України, і у 1969 р. вона була прийнята на посаду молодшого наукового співробітника відділу грипу та гострих респіраторних захворювань. 31969 по 1980 рр. А.О. Руденко працювала молодшим науковим співробітником, з 1980 по 1990 рр. - старшим науковим співробітником відділу нейроінфрекцій. В 1979 р. вона захистила кандидатську дисертацію, в 1980 р. отримала звання старшого наукового співробітника, в 1989 р. захистила докторську дисертацію, а у 2006 р. їй було присвоєно вчене звання просресора. 31990 р. Антоніна Олексіївна є беззмінним завідувачем відділу нейроінфекцій Інституту - натепер ДУ «Інститут епідеміології та інфекційних хвороб ім. Л.В. Громашевського НАМН України».

Все своє життя Антоніна Олексіївна присвятила боротьбі з інфекційними хворобами людини та поклала на вівтар науки. Нею зроблено значний внесок у розвиток інфектології, створення вітчизняної школи інфекціоністів, розробку та впровадження стандартів діагностично-лікувального процесу та стаціонарної допомоги інфекційним хворим. Окремим напрямком діяльності А.О. Руденко було вивчення патогенезу механізмів розвитку легеневих ускладнень при грипі та інших гострих респіраторних захворюваннях, уражень нервової системи вірусної, в тому числі герпетичної, вірусно-бактерійної та бактерійної природи, фрормування затяжного та рецидивного їх перебігу; удосконаленню лікування та профрілактики несприятливих наслідків. Цей напрямок згуртував навколо Антоніни Олексіївни численних молодих вчених, учнів, колег.

Результати наукової діяльності та багаторічний досвід практикуючого лікаря А.О. Руденко знайшли відображення у значній кількості нормативних та інструктивних документів Кабінету Міністрів і МОЗ України (з сальмонельозу, гострих кишкових інсрекцій, менінгококової інсрекції, токсоплазмозу), наказу «Про удосконалення інсрекційної служби в Україні». Під її керівництвом і за безпосередньої участі були створені тимчасові стандарти діагностично-лікувального процесу стаціонарної допомоги інфекційним хворим та Державні соціальні стандарти України з надання медичної допомоги інфекційним хворим в амбулаторно-поліклінічних умовах тощо.

Антоніна Олексіївна $€$ автором понад 350 наукових праць і 5 патентів. Під її керівництвом захищено 3 кандидатські дисертації і зараз виконуються 2 кандидатські й 2 докторські дисертації; вона багаторазово виступала рецензентом та опонентом дисертаційних робіт, надаючи суттєву допомогу їх виконавцям.

Впродовж 1992-2004 рр. А.О. Руденко була головним позаштатним інсрекціоністом Міністерства охорони здоров'я України, віддаючи багато сил і часу організації боротьби 3 інсрекційними хворобами: особисто виїжджала на спалахи, брала безпосередню участь в їх ліквідації, активно впроваджувала нові методи лікування, діагностики та профрілактики в практику інфекційної служби країни. Працювала членом центральної Атестаційної комісії при МОЗ України; 


\section{ЮВІЛЕї ТА ПОДІї}

членом комісії з гострих в'ялих паралічів, комісії з організації, забезпечення та координації робіт по централізованій закупівлі вакцин, інших імунобіологічних препаратів і дезінфрекційних засобів. Вона член редколегії журналів «Інфекційні хвороби», «Сучасні інфекції», «Проорілактична медицина»; протягом багатьох років $є$ членом вченої ради дУ «Інститут епідеміології та інорекційних хвороб ім. Л.В. Громашевського НАМН України» та спеціалізованої вченої ради із захисту кандидатських і докторських дисертацій.

За внесок у боротьбу з інфекційними хворобами А.О. Руденко неодноразово отримувала почесні державні відзнаки УРСР, почесні грамоти НАМН України, нагороджена почесним званням «Заслужений лікар України», медалями «Ветеран праці», «До 1500-річчя Києва», «Агапіт Печерський», «75 років оборони Києва». У жовтні 2016 р. Антоніна Олексіївна однією з перших у галузі була нагоро- джена почесною відзнакою НАМН України «Знак пошани».

А.О. Руденко, будучи відомим в Україні та за її межами фрахівцем, видатним науковцем-клініцистом, принциповим і вимогливим, завжди залишається красивою, привітною, доброзичливою жінкою, яка викликає глибоку повагу та любов колег і пацієнтів.

щиро вітаємо вельмишановну Антоніну Олексіївну Руденко з ювілеєм і бажаємо їй безмежного щастя, міцного здоров'я, невичерпної життєвої енергії, втілення творчих планів і натхнення в роботі на довгі роки!

Колектив Інституту епідеміології та інфекційних хвороб ім. Л.В. Громашевського, президія ГО ВАІ, редакція журналу «Інфрекційні хвороби».

Отримано 20.09.2016 p. 